\title{
Two New Triterpene Saponins from Eryngium campestre
}

\author{
Murat Kartal ${ }^{a}$ Anne-Claire Mitaine-Offer,${ }^{b}$ Mahmoud Abu-Asaker,${ }^{a}$ Tomofumi Miyamoto, ${ }^{c}$ \\ Ihsan CALIS ${ }^{d}$ Hildebert WAgNER, ${ }^{e}$ and Marie-Aleth LACAILle-Dubois $*, b$ \\ ${ }^{a}$ Pharmacognosy Department, Faculty of Pharmacy, Ankara University; 06100 Tandogan-Ankara, Turkey: ${ }^{b}$ Laboratoire de \\ Pharmacognosie, UMIB, UPRES-EA 3660, Faculté de Pharmacie, Université de Bourgogne; 7, Bd. Jeanne D'Arc, BP \\ 87900, 21079 Dijon Cedex, France: ' Graduate School of Pharmaceutical Sciences, Kyushu University; Fukuoka 812- \\ 8582, Japan: 'Pharmacognosy Department, Faculty of Pharmacy, Hacettepe University; 06100 Ankara, Turkey: and \\ ${ }^{e}$ Center of Pharmaresearch, Pharmaceutical Biology, Munich University; 81377 Munich, Germany. \\ Received January 28, 2005; accepted April 14, 2005
}

Two new triterpene saponins, 3- $O$ - $\beta$-D-glucopyranosyl-( $1 \rightarrow 2)-[\alpha$-L-rhamnopyranosyl-(1 $\rightarrow 4)]-\beta$-D-glucuronopyranosyl-22- $O$-angeloyl-R1-barrigenol (1) and $3-O$ - $\beta$-D-glucopyranosyl- $(1 \rightarrow 2)$-[ $\alpha$-L-rhamnopyranosyl$(1 \rightarrow 4)]-\beta$-D-glucuronopyranosyl-22- $O$ - $\beta, \beta$-dimethylacryloyl-A1-barrigenol (2), were isolated from the roots of Eryngium campestre (Apiaceae). Their structures were established mainly by 2D NMR techniques and mass spectrometry.

Key words Eryngium campestre; Apiaceae; triterpene saponin; R1-barrigenol; A1-barrigenol

Eryngium genus (Apiaceae) is represented by 317 species, subspecies and varieties. ${ }^{1)}$ The species E. campestre L. grows in most parts of Europe and northern Africa and has been introduced into North America. In the flora of Turkey and East Aegean Islands, ${ }^{2}$ Eryngium genus is represented by 23 species, and E. campestre is known in Turkish folk-medicine as "Bogadikeni". Infusions of the aerial and root parts are used as an antitussive, diuretic, appetizer, stimulant and aphrodisiac. $^{3)}$ Previous phytochemical studies on $E$. campestre described the isolation of flavonoids from the aerial parts, ${ }^{4,5)}$ and from the roots, monoterpene glycosides of the cyclohexanone type, ${ }^{6}$ coumarin derivatives, ${ }^{7)}$ and small amounts of saponins. ${ }^{8)}$ We describe in this paper the isolation and structural elucidation of two new triterpene saponins, $\mathbf{1}$ and $\mathbf{2}$, from the roots of $E$. campestre.

A concentrated $n$-BuOH-soluble fraction of the $\mathrm{MeOH}$ extract of the roots of $E$. campestre was subjected to multiple chromatographic steps over silica gel to yield compounds 1 and 2. Their structures were elucidated mainly by $600 \mathrm{MHz}$ NMR analysis, including $1 \mathrm{D}$ and $2 \mathrm{D}$ NMR $\left({ }^{1} \mathrm{H}-{ }^{1} \mathrm{H}\right.$ COSY, TOCSY, NOESY, HSQC, HMBC) spectroscopy.

Compound 1, a white amorphous powder, exhibited in the HR-ESI-MS (positive-ion mode) a pseudo-molecular ion peak at $m / z 1095.5399[\mathrm{M}+\mathrm{Na}]^{+}($Calcd 1095.5352), consistent with a molecular formula of $\mathrm{C}_{53} \mathrm{H}_{84} \mathrm{O}_{22} \mathrm{Na}$. Its FAB-MS (negative-ion mode) showed a quasi-molecular ion peak at $m / z 1071[\mathrm{M}-\mathrm{H}]^{-}$, indicating a molecular weight of 1072 . Other fragment ion peaks were observed at $\mathrm{m} / \mathrm{z} 925$ $[(\mathrm{M}-\mathrm{H})-146]^{-}$and $909[(\mathrm{M}-\mathrm{H})-162]^{-}$which revealed the elimination of one terminal 6-desoxyhexosyl and one terminal hexosyl moiety.

The structure of the aglycon of $\mathbf{1}$ was recognized to be the triterpene R1-barrigenol by ${ }^{1} \mathrm{H}$ - and ${ }^{13} \mathrm{C}-\mathrm{NMR}$ analysis (Table 1) using the correlations observed in COSY, HMQC, HSQC and NOESY spectra, and was in full agreement with literature data. ${ }^{9)}$ The ${ }^{1} \mathrm{H}-\mathrm{NMR}$ spectrum of $\mathbf{1}$ showed signals for seven angular methyl groups as singlets, one olefinic proton at $\delta_{\mathrm{H}} 5.54(1 \mathrm{H}$, brt $, J=3.0 \mathrm{~Hz}, \mathrm{H}-12)$, five oxygen bearing methine protons at $\delta_{\mathrm{H}} 3.17(1 \mathrm{H}, \mathrm{dd}, J=10.5,5.5 \mathrm{~Hz}, \mathrm{H}-$ 3), 4.15 (H-21), 4.39 (1H, d, $J=3.6 \mathrm{~Hz}, \mathrm{H}-15), 4.55$ (1H, d,
$J=3.6 \mathrm{~Hz}, \mathrm{H}-16), 6.27(1 \mathrm{H}, \mathrm{d}, J=7.4 \mathrm{~Hz}, \mathrm{H}-22)$, and one primary alcoholic function at $\delta_{\mathrm{H}} 3.79,3.83(2 \mathrm{H}, \mathrm{d}, J=12.7 \mathrm{~Hz}$, $\mathrm{H}-28)$. In the HMBC spectrum, crosspeaks between $\delta_{\mathrm{H}} 1.91$ $(3 \mathrm{H}, \mathrm{s}, \mathrm{H}-27)$ and $\delta_{\mathrm{C}} 67.6(\mathrm{C}-15)$, and between $\delta_{\mathrm{H}} 1.51(3 \mathrm{H}$, $\mathrm{s}, \mathrm{H}-29), \delta_{\mathrm{H}} 1.53(3 \mathrm{H}, \mathrm{s}, \mathrm{H}-30)$ and $\delta_{\mathrm{C}} 71.3(\mathrm{C}-21)$ allowed the location of two secondary alcoholic functions at $\mathrm{C}-15$ and $\mathrm{C}-21$. The proton at $\delta_{\mathrm{H}} 6.27(1 \mathrm{H}, \mathrm{d}, J=7.4 \mathrm{~Hz})$, showed HMBC connectivities with the C-28 at $\delta_{\mathrm{C}} 64.8$, the C-21 at $\delta_{\mathrm{C}} 71.3$, the C-16 at $\delta_{\mathrm{C}} 72.8$ and the C-18 at $\delta_{\mathrm{C}} 54.0$, which revealed its assignment at position 22 . The absolute configuration of $\mathrm{C}-3, \mathrm{C}-15, \mathrm{C}-16, \mathrm{C}-21$, and $\mathrm{C}-22$ of the $\mathrm{R} 1-\mathrm{bar}-$ rigenol is determined from a NOESY experiment and by the multiplicity and coupling constants of carbinol protons. In the NOESY spectrum, correlations between $\delta_{\mathrm{H}} 3.17(1 \mathrm{H}, \mathrm{dd}$, $J=10.5,5.5 \mathrm{~Hz}, \mathrm{H}-3)$ and $\delta_{\mathrm{H}} 0.72(\mathrm{H}-5)$ and $\delta_{\mathrm{H}} 1.13(3 \mathrm{H}, \mathrm{s}$, $\mathrm{H}-23)$, between $\delta_{\mathrm{H}} 4.39(1 \mathrm{H}, \mathrm{d}, J=3.6 \mathrm{~Hz}, \mathrm{H}-15)$ and $\delta_{\mathrm{H}} 0.98$ $(3 \mathrm{H}, \mathrm{s}, \mathrm{H}-26)$, and between $\delta_{\mathrm{H}} 4.55(1 \mathrm{H}, \mathrm{d}, J=3.6 \mathrm{~Hz}, \mathrm{H}-16)$ and $\delta_{\mathrm{H}} 3.79,3.83(2 \mathrm{H}, \mathrm{d}, J=12.7 \mathrm{~Hz}, \mathrm{H}-28)$, confirmed the proposed absolute configuration of the R1-barrigenol. ${ }^{9)}$ For

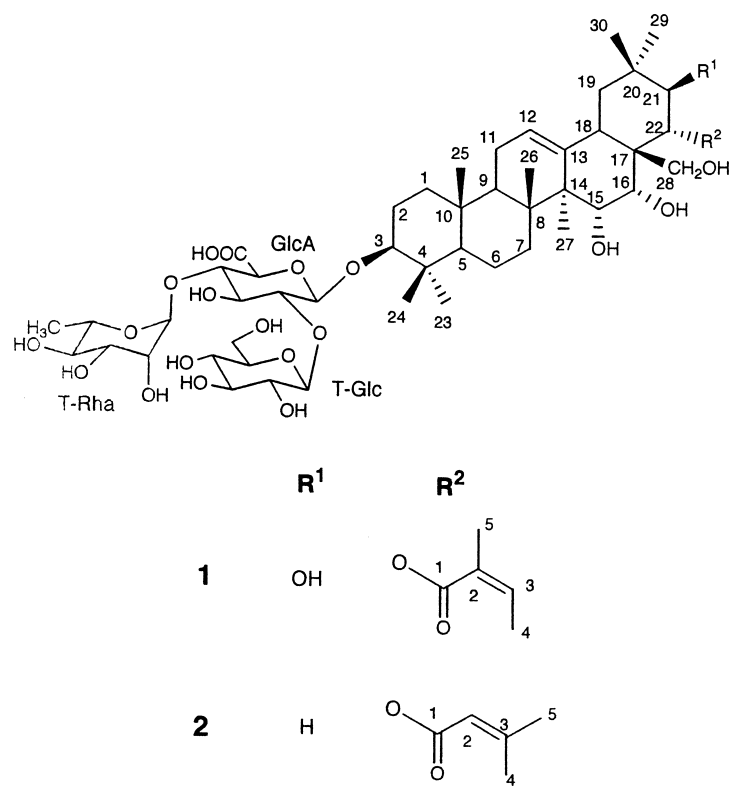

(C) 2005 Pharmaceutical Society of Japan 
Table 1. ${ }^{1} \mathrm{H}-(600 \mathrm{MHz})$ and ${ }^{13} \mathrm{C}-(150 \mathrm{MHz})$ NMR Data of the Aglycons and Acyl Groups of Compounds $\mathbf{1}$ and 2 (Pyridine- $d_{5}, \delta$ in ppm)

\begin{tabular}{|c|c|c|c|c|}
\hline \multirow{2}{*}{ Position } & \multicolumn{2}{|r|}{1} & \multicolumn{2}{|r|}{2} \\
\hline & ${ }^{13} \mathrm{C}$ & ${ }^{1} \mathrm{H}$ & ${ }^{13} \mathrm{C}$ & ${ }^{1} \mathrm{H}$ \\
\hline \multicolumn{5}{|l|}{ Agly } \\
\hline 1 & 38.5 & $0.72,1.30$ & 38.5 & $0.74,1.32$ \\
\hline 2 & 26.0 & $1.85,2.18$ & 26.0 & $1.87,2.20$ \\
\hline 3 & 89.5 & $3.17 \mathrm{dd}(10.5,5.5)$ & 89.4 & $3.18 \mathrm{dd}(10.5,5.5)$ \\
\hline 4 & 39.1 & - & 39.2 & - \\
\hline 5 & 55.2 & 0.72 & 55.0 & 0.74 \\
\hline 6 & 18.6 & nd & 18.8 & nd \\
\hline 7 & 36.5 & $1.98,2.10$ & 36.4 & $2.02,2.12$ \\
\hline 8 & 41.0 & - & 41.0 & - \\
\hline 9 & 46.8 & 1.68 & 46.6 & 1.68 \\
\hline 10 & 36.6 & - & 36.6 & - \\
\hline 11 & 23.5 & $1.78,1.81$ & 23.5 & $1.81,1.87$ \\
\hline 12 & 125.5 & 5.54 brt (3.0) & 125.0 & 5.56 brt (3.0) \\
\hline 13 & 141.4 & - & 143.8 & - \\
\hline 14 & 47.6 & - & 47.0 & - \\
\hline 15 & 67.6 & $4.39 \mathrm{~d}(3.6)$ & 66.9 & 4.28 \\
\hline 16 & 72.8 & $4.55 \mathrm{~d}(3.6)$ & 74.3 & 4.54 \\
\hline 17 & nd & - & nd & - \\
\hline 18 & 54.0 & $3.12 \mathrm{br} \mathrm{s}$ & 41.3 & $3.04 \mathrm{brs}$ \\
\hline 19 & 35.2 & $2.30,2.95$ & 46.8 & $1.38,2.86 \mathrm{t}(13.8)$ \\
\hline 20 & nd & - & 31.2 & - \\
\hline 21 & 71.3 & 4.15 & 41.3 & $2.00,2.76 \mathrm{t}(11.9)$ \\
\hline 22 & 80.9 & $6.27 \mathrm{~d}(7.4)$ & 71.8 & $6.12 \mathrm{dd}(11.9,5.0)$ \\
\hline 23 & 27.6 & $1.13 \mathrm{~s}$ & 27.6 & $1.14 \mathrm{~s}$ \\
\hline 24 & 16.4 & $1.05 \mathrm{~s}$ & 16.5 & $1.06 \mathrm{~s}$ \\
\hline 25 & 15.3 & $0.81 \mathrm{~s}$ & 15.4 & $0.82 \mathrm{~s}$ \\
\hline 26 & 17.5 & $0.98 \mathrm{~s}$ & 17.2 & $1.06 \mathrm{~s}$ \\
\hline 27 & 21.0 & $1.91 \mathrm{~s}$ & 21.0 & $1.87 \mathrm{~s}$ \\
\hline 28 & 64.8 & $\begin{array}{l}3.79 \mathrm{~d}(12.7) \\
3.83 \mathrm{~d}(12.7)\end{array}$ & 62.5 & $\begin{array}{l}3.62 \mathrm{~d}(10.5), \\
3.79 \mathrm{~d}(10.5)\end{array}$ \\
\hline 29 & 28.7 & $1.51 \mathrm{~s}$ & 33.2 & $1.06 \mathrm{~s}$ \\
\hline 30 & 27.6 & $1.53 \mathrm{~s}$ & 24.8 & $1.29 \mathrm{~s}$ \\
\hline \multicolumn{5}{|l|}{ Ang } \\
\hline 1 & 169.2 & - & & \\
\hline 2 & 128.8 & - & & \\
\hline 3 & 136.6 & $5.90 \mathrm{qd}(7.0,1.0)$ & & \\
\hline 4 & 15.5 & $2.06 \mathrm{brdd}(7.0,1.0)$ & & \\
\hline 5 & 20.5 & $2.00 \mathrm{brs}$ & & \\
\hline \multicolumn{5}{|l|}{ dMA } \\
\hline 1 & & & 167.0 & - \\
\hline 2 & & & 117.0 & $5.62 \mathrm{brs}$ \\
\hline 3 & & & 157.0 & - \\
\hline 4 & & & 20.0 & $2.20 \mathrm{~s}$ \\
\hline 5 & & & 26.7 & $1.68 \mathrm{~s}$ \\
\hline
\end{tabular}

nd: not determined. Overlapped proton NMR signals are reported without designated multiplicity. Ang: angelic acid, dMA: $\beta, \beta$-dimethyl-acrylic acid.

$\mathrm{C}-21$ and C-22, the NOESY correlations between $\delta_{\mathrm{H}} 6.27$ $(1 \mathrm{H}, \mathrm{d}, J=7.4 \mathrm{~Hz}, \mathrm{H}-22)$ and $\delta_{\mathrm{H}} 1.53(3 \mathrm{H}, \mathrm{s}, \mathrm{H}-30)$ and $\delta_{\mathrm{H}}$ $3.12(1 \mathrm{H}$, br s, $\mathrm{H}-18)$ revealed a $\beta$-axial position of the $\mathrm{H}-22$, and its multiplicity as a doublet and its coupling constant of $7.4 \mathrm{~Hz}$ suggested an $\alpha$-axial position of $\mathrm{H}-21$. Moreover, the deshielded signal of $\mathrm{H}-22$ at $\delta_{\mathrm{H}} 6.27$ and HMBC correlations between $\delta_{\mathrm{H}} 6.27(\mathrm{H}-22)$ and $\delta_{\mathrm{C}} 169.2(\mathrm{COO})$ suggested that position 22 was acylated. Two vinylic methyl groups at $\delta_{\mathrm{H}}$ $2.00(3 \mathrm{H}, \mathrm{br} \mathrm{s})$ and $\delta_{\mathrm{H}} 2.06(3 \mathrm{H}, \mathrm{brdd}, J=7.0,1.0 \mathrm{~Hz})$, correlating in the COSY spectrum with a vinylic proton at $\delta_{\mathrm{H}} 5.90$ $(1 \mathrm{H}, \mathrm{qd}, J=7.0,1.0 \mathrm{~Hz})$, suggested the presence of an angeloyl residue. This proton at $\delta_{\mathrm{H}} 5.90$, which is not influenced by the carbonyl function, revealed a $Z$ double bond, in opposition to a $E$ orientation in the tigloyl residue. At this stage, the sugar part of compound $\mathbf{1}$ needed to be deter-
Table 2. ${ }^{1} \mathrm{H}-(600 \mathrm{MHz})$ and ${ }^{13} \mathrm{C}-(150 \mathrm{MHz})$ NMR Data of the Sugar Moieties of Compounds 1 and 2 (Pyridine- $d_{5}, \delta$ in ppm) $)^{a}$

\begin{tabular}{|c|c|c|c|c|}
\hline \multirow{2}{*}{ Position } & \multicolumn{2}{|r|}{1} & \multicolumn{2}{|r|}{2} \\
\hline & ${ }^{13} \mathrm{C}$ & ${ }^{1} \mathrm{H}$ & ${ }^{13} \mathrm{C}$ & ${ }^{1} \mathrm{H}$ \\
\hline \multicolumn{5}{|l|}{ GlcA } \\
\hline 1 & 104.6 & $4.81 d(7.6)$ & 104.6 & $4.82 d(7.6)$ \\
\hline 2 & 80.5 & $4.47 t(8.4)$ & 80.5 & $4.47 t(8.3)$ \\
\hline 3 & 76.0 & 4.28 & 76.0 & 4.28 \\
\hline 4 & 79.7 & 4.62 & 79.7 & 4.63 \\
\hline 5 & 78.4 & 4.45 & 78.4 & 4.43 \\
\hline 6 & 176.9 & - & 176.8 & - \\
\hline \multicolumn{5}{|l|}{ T-Glc } \\
\hline 1 & 104.3 & $5.43 d(7.4)$ & 104.3 & $5.44 d(7.4)$ \\
\hline 2 & 76.0 & $4.05 \mathrm{t}(8.4)$ & 76.0 & $4.07 \mathrm{t}(7.4)$ \\
\hline 3 & 77.4 & $4.21 \mathrm{t}(8.9)$ & 77.4 & $4.21 \mathrm{t}(9.2)$ \\
\hline 4 & 71.3 & $4.09 \mathrm{t}(9.3)$ & 71.3 & $4.10 \mathrm{t}(9.4)$ \\
\hline 5 & 78.0 & 3.91 & 78.0 & 3.91 \\
\hline 6 & 62.5 & $4.28,4.53$ & 62.5 & $4.29,4.54$ \\
\hline \multicolumn{5}{|l|}{ T-Rha } \\
\hline 1 & 101.6 & $5.97 \mathrm{brs}$ & 101.6 & 5.99 brs \\
\hline 2 & 71.4 & $4.99 \mathrm{brs}$ & 71.4 & $5.00 \mathrm{brs}$ \\
\hline 3 & 71.5 & 4.62 & 71.5 & 4.62 \\
\hline 4 & 73.4 & 4.26 & 73.4 & 4.26 \\
\hline 5 & 69.7 & $4.90 \mathrm{dq}(9.3,6.0)$ & 69.7 & $4.91 \mathrm{dq}(9.3,6.2)$ \\
\hline 6 & 18.1 & $1.62 \mathrm{~d}(6.0)$ & 18.1 & $1.62 \mathrm{~d}(6.2)$ \\
\hline
\end{tabular}

a) Chemical shifts of substituted residues are italicized. nd: not determined. Overlapped proton NMR signals are reported without designated multiplicity.

mined. The ${ }^{1} \mathrm{H}-\mathrm{NMR}$ spectrum of $\mathbf{1}$ displayed signals for three anomeric protons at $\delta_{\mathrm{H}} 4.81(1 \mathrm{H}, \mathrm{d}, J=7.6 \mathrm{~Hz}), 5.43$ $(1 \mathrm{H}, \mathrm{d}, J=7.4 \mathrm{~Hz})$, and $5.97(1 \mathrm{H}, \mathrm{br})$, which gave correlations, in the HSQC spectrum, with anomeric carbon signals at $\delta_{\mathrm{C}} 104.6,104.3$, and 101.6, respectively. The ring protons of the monosaccharide residues were assigned starting from the readily identifiable anomeric protons by means of COSY, TOCSY, HSQC, HMBC experiments (Table 2). Units of one $\beta$-D-glucuronopyranosyl (GlcA), one $\beta$-D-glucopyranosyl (Glc), and one $\alpha$-L-rhamnopyranosyl (Rha) were identified. The relatively large ${ }^{3} J_{\mathrm{H}-1, \mathrm{H}-2}$ values of the anomeric protons of GlcA and Glc (7.6, 7.4 Hz, respectively) indicated a $\beta$ anomeric orientation for GlcA and Glc, and the multiplicity of the anomeric proton of Rha (brs) indicated an $\alpha$ anomeric orientation. ${ }^{10)}$ Correlations observed in the HMBC spectrum between signals at $\delta_{\mathrm{H}} 4.81(1 \mathrm{H}, \mathrm{d}, J=7.6 \mathrm{~Hz}, \mathrm{GlcA}-1)$ and $\delta_{\mathrm{C}}$ 89.5 (C-3), and in the NOESY spectrum between $\delta_{\mathrm{H}} 4.81$ (GlcA-1) and $\delta_{\mathrm{H}} 3.17(1 \mathrm{H}, \mathrm{dd}, J=10.5,5.5 \mathrm{~Hz}, \mathrm{H}-3)$, confirmed the substitution at the C-3 position of the R-1 barrigenol by a $3-O-\beta$-D-glucuronopyranose. The assignments of the ${ }^{1} \mathrm{H}$ - and ${ }^{13} \mathrm{C}$-NMR signals of Glc and Rha attached to GlcA by a $(1 \rightarrow 2)$ and a $(1 \rightarrow 4)$ linkage, respectively, were deduced from the TOCSY, NOESY, HSQC and HMBC spectra. Cross-peaks in the HMBC spectrum between an anomeric signal at $\delta_{\mathrm{H}} 5.43(1 \mathrm{H}, \mathrm{d}, J=7.4 \mathrm{~Hz})$ and the deshielded carbon at $\delta_{\mathrm{C}} 80.5$ (GlcA-2), and between another anomeric signal at $\delta_{\mathrm{H}} 5.97(1 \mathrm{H}, \mathrm{brs})$ and a signal at $\delta_{\mathrm{C}} 79.7(\mathrm{GlcA}-4)$, suggested a 2, 4 substitution of this glucuronic acid by one terminal glucose (T-Glc) and one terminal rhamnose (T-Rha), respectively. These substitutions were confirmed by a reverse correlation between $\delta_{\mathrm{H}} 4.62(\mathrm{GlcA}-4)$ and $\delta_{\mathrm{C}} 101.6$ (T-Rha$1)$, and in the NOESY spectrum by a correlation between $\delta_{\mathrm{H}} 4.47(1 \mathrm{H}, \mathrm{t}, J=8.4 \mathrm{~Hz}, \mathrm{GlcA}-2)$ and $\delta_{\mathrm{H}} 5.43(1 \mathrm{H}, \mathrm{d}$, $J=7.4 \mathrm{~Hz}$, T-Glc-1). The structure of 1 was thus established 
as 3-O- $\beta$-D-glucopyranosyl-( $1 \rightarrow 2)$-[ $\alpha$-L-rhamnopyranosyl$(1 \rightarrow 4)]-\beta$-D-glucuronopyranosyl-22- $O$-angeloyl-R1-barrigenol, a new natural compound.

Compound 2, a white amorphous powder, exhibited in the HR-ESI-MS (positive-ion mode) a pseudo-molecular ion peak at $\mathrm{m} / \mathrm{z} 1079.5356[\mathrm{M}+\mathrm{Na}]^{+}(\mathrm{Calcd} 1079.5403)$, consistent with a molecular formula of $\mathrm{C}_{53} \mathrm{H}_{84} \mathrm{O}_{21} \mathrm{Na}$. Its FAB-MS (negative-ion mode) displayed a quasi-molecular ion peak $[\mathrm{M}-\mathrm{H}]^{-}$at $m / z \quad 1055$ indicating a molecular weight of 1056, which differs from 1 by $16 \mathrm{amu}$. Other fragment ion peaks were observed at $\mathrm{m} / z 909[(\mathrm{M}-\mathrm{H})-146]^{-}$and 893 $[(\mathrm{M}-\mathrm{H})-162]^{-}$which revealed the elimination of one terminal 6-desoxyhexosyl and one terminal hexosyl moiety. The signals of the sugar part of 2, assigned from 1D and 2D NMR spectra, were almost superimposable on those of $\mathbf{1}$. The differences between the two molecules were thus located at the aglycon moiety. The ${ }^{1} \mathrm{H}-\mathrm{NMR}$ spectrum of $\mathbf{2}$ showed signals for seven angular methyl groups as singlets, one olefinic proton at $\delta_{\mathrm{H}} 5.56(1 \mathrm{H}$, brt, $J=3.0 \mathrm{~Hz}, \mathrm{H}-12)$, four oxygen bearing methine protons at $\delta_{\mathrm{H}} 3.18(1 \mathrm{H}, \mathrm{dd}, J=10.5$, $5.5 \mathrm{~Hz}, \mathrm{H}-3), 4.28(\mathrm{H}-15), 4.54(\mathrm{H}-16)$, and $6.12(1 \mathrm{H}, \mathrm{dd}$, $J=11.9,5.0 \mathrm{~Hz}, \mathrm{H}-22)$, and one primary alcoholic function at $\delta_{\mathrm{H}} 3.62,3.79(2 \mathrm{H}, \mathrm{d}, J=10.5 \mathrm{~Hz}, \mathrm{H}-28)$. In the HMBC spectrum, crosspeaks between $\delta_{\mathrm{H}} 1.06(3 \mathrm{H}, \mathrm{s}, \mathrm{H}-29), \delta_{\mathrm{H}} 1.29$ $(3 \mathrm{H}, \mathrm{s}, \mathrm{H}-30)$ and two methylene carbons at $\delta_{\mathrm{C}} 41.3$ and 46.8 , revealed the absence of the hydroxyl group at $\mathrm{C}-21$. The deshielded proton at $\delta_{\mathrm{H}} 6.12(1 \mathrm{H}, \mathrm{dd}, J=11.9,5.0 \mathrm{~Hz})$, showing $\mathrm{HMBC}$ connectivities with the $\mathrm{C}-16$ at $\delta_{\mathrm{C}} 74.3$, can be assigned at position 22, which must be acylated. These values are in accordance with the literature data of A-1 barrigenol as an aglycon. ${ }^{11)}$ In the HMBC spectrum, correlations between two vinylic methyl groups at $1.68(3 \mathrm{H}, \mathrm{s})$ and 2.20 $(3 \mathrm{H}, \mathrm{s})$ and one $s p^{2}$ quaternary carbon at $\delta_{\mathrm{C}} 157.0$ and a $s p^{2}$ methine carbon at $\delta_{\mathrm{C}} 117.0$ were observed. These signals belonged to $\beta, \beta$-dimethyl-acrylic acid acylating the C-22 position. This group rarely encountered acylating the aglycon of saponins, was already described esterifying camelliagenin A from Harpullia cupanioides (Sapindaceae) but at the C-16 position. ${ }^{12)}$ On the basis of the above results, the structure of 2 was established as 3-O- $\beta$-D-glucopyranosyl- $(1 \rightarrow 2)$ - $[\alpha-\mathrm{L}-$ rhamnopyranosyl- $(1 \rightarrow 4)]-\beta$-D-glucuronopyranosyl-22-O$\beta, \beta$-dimethylacryloyl-A1-barrigenol, a new natural saponin.

R1 and A1-barrigenol are aglycons already isolated from plants belonging to different families, especially from the Apiales order like Apiaceae (genera Hydrocotyle, ${ }^{13)}$ Hacquetia, ${ }^{14)}$ Steganotaenia, ${ }^{15)}$ Sanicula ${ }^{16)}$ ) and Pittosporaceae (Pittosporum $\left.^{9}\right)$. Therefore, it is not surprising to find them as aglycons of saponins from an Eryngium species, but the acylation of C-22 by a dimethylacryloyl unit is rare amoung triterpene saponins.

\section{Experimental}

Optical rotations were taken with a Rudolph Autopol IV Polarimeter using a sodium lamp operating at $589 \mathrm{~nm}$. The 1D and 2D NMR spectra $\left({ }^{1} \mathrm{H}-{ }^{1} \mathrm{H}\right.$ COSY, TOCSY, HSQC, and HMBC) were performed using a UNITY-600 spectrometer at an operating frequency of $600 \mathrm{MHz}$ on a Varian INOVA 600 instrument equipped with a SUN 4 L-X computer system (600 MHz for ${ }^{1} \mathrm{H}$ and $150 \mathrm{MHz}$ for ${ }^{13} \mathrm{C}$ spectra). The carbon type $\left(\mathrm{CH}_{3}, \mathrm{CH}_{2}\right.$, $\mathrm{CH})$ was determined by DEPT experiments. All chemical shifts $(\delta)$ are given in $\mathrm{ppm}$, and the samples were solubilized in pyridine- $d_{5}\left(\delta_{\mathrm{C}} 149.3\right.$,
135.8, 123.5). High-resolution ESI mass spectrometry (HR-ESI-MS) (positive-ion mode) was carried out on a Q-TOF 1-micromass spectrometer. FAB-MS (negative-ion mode, glycerol matrix) were obtained on a JEOL SX 102 mass spectrometer. TLC employed precoated silica gel plates $60 \mathrm{~F}_{254}$ (Merck). For saponins, the TLC solvent system $\mathrm{CHCl}_{3}-\mathrm{MeOH}-\mathrm{H}_{2} \mathrm{O}$ $(61: 32: 7)$ was used. The spray reagent for saponins was vanillin $(1 \%$ in EtOH) and aqueous $\mathrm{H}_{2} \mathrm{SO}_{4}(30 \%)$. Isolations were carried out using a medium-pressure liquid chromatography (MPLC) system [Büchi 681 pump Rheodyne injector, Büchi column $(46 \times 2.5 \mathrm{~cm})$, LiChroprep RP-18 (25$40 \mu \mathrm{m})$, Büchi 684 fraction collector]. For column chromatography, Si gel $60(63-200 \mu \mathrm{m}$, Merck) was used.

Plant Material In August 2003, E. campestre was collected from Balıkesir-Edremit, Turkey and identified by Pr. Dr. Hayri Duman (Department of Biology, Faculty of Sciences, Gazi University, Ankara, Turkey). A voucher specimen (AEF 22964) was deposited in the herbarium of the Faculty of Pharmacy, Ankara University, Ankara, Turkey.

Extraction and Isolation The dried powdered roots $(150 \mathrm{~g})$ were extracted with $\mathrm{MeOH}$ under reflux for $24 \mathrm{~h}$. The $\mathrm{MeOH}$ extract $(17.2 \mathrm{~g}$ ) was concentrated to dryness, and the residue was dissolved in an $\mathrm{H}_{2} \mathrm{O}-\mathrm{MeOH}$ mixture $(9: 1)$, then partitioned with $n$-butanol $(100 \mathrm{ml})$ saturated with $\mathrm{H}_{2} \mathrm{O}$. The $n$ - $\mathrm{BuOH}$ layer was concentrated to dryness, and the residue $(9.5 \mathrm{~g})$ was separated by column chromatography on $\mathrm{Si}$ gel eluted with $\mathrm{CH}_{2} \mathrm{Cl}_{2}-\mathrm{MeOH}-\mathrm{H}_{2} \mathrm{O}$ mixtures $(80: 20: 2,750 \mathrm{ml} ; 70: 30: 3 ; 60: 40: 4$; $50: 50: 5$, each $1000 \mathrm{ml}$ ), yielding 13 main fractions, $\mathrm{A}-\mathrm{M}$. The fraction $\mathrm{H}$ (310 mg), eluted with $\mathrm{CH}_{2} \mathrm{Cl}_{2}-\mathrm{MeOH}-\mathrm{H}_{2} \mathrm{O}(60: 40: 4)$, was purified by MPLC on a LiChroprep RP-18 column eluted with $\mathrm{MeOH}-\mathrm{H}_{2} \mathrm{O}$ mixtures ( $50: 50$ to $\mathrm{MeOH}$; in steps of $5 \% \mathrm{MeOH}$, each $100 \mathrm{ml})$ to give $\mathbf{1}(11 \mathrm{mg}$ ) and 2 (5 mg).

Compound 1: A white amorphous powder; $[\alpha]_{\mathrm{D}}^{25}-33.0^{\circ}(c=0.03$ in $\mathrm{MeOH}$ ); ${ }^{1} \mathrm{H}-\mathrm{NMR}$ (pyridine- $d_{5}, 600 \mathrm{MHz}$ ) and ${ }^{13} \mathrm{C}-\mathrm{NMR}$ (pyridine- $d_{5}$, $150 \mathrm{MHz}$ ), see Tables 1 and 2; Positive HR-ESI-MS $m / z \quad 1095.5399$ $[\mathrm{M}+\mathrm{Na}]^{+}\left(\right.$Calcd 1095.5352); Negative FAB-MS m/z $1071[\mathrm{M}-\mathrm{H}]^{-}, 925$ $[(\mathrm{M}-\mathrm{H})-146]^{-}, 909[(\mathrm{M}-\mathrm{H})-162]^{-}$

Compound 2: A white amorphous powder; $[\alpha]_{\mathrm{D}}^{25}-33.0^{\circ}(c=0.03$ in $\mathrm{MeOH}$ ); ${ }^{1} \mathrm{H}-\mathrm{NMR}$ (pyridine- $d_{5}, 600 \mathrm{MHz}$ ) and ${ }^{13} \mathrm{C}-\mathrm{NMR}$ (pyridine- $d_{5}$, $150 \mathrm{MHz}$ ), see Tables 1 and 2; Positive HR-ESI-MS $\mathrm{m} / \mathrm{z} 1079.5356$ $[\mathrm{M}+\mathrm{Na}]^{+}\left(\right.$Calcd 1079.5403); Negative FAB-MS m/z $1055[\mathrm{M}-\mathrm{H}]^{-}, 909$ $[(\mathrm{M}-\mathrm{H})-146]^{-}, 893[(\mathrm{M}-\mathrm{H})-162]^{-}$.

\section{References}

1) Wörz A., Stuttgarter Beitr. Naturk. Ser. A, 596, 1-48 (1999).

2) Güner A., Özhatay N., Ekim T., Baser K. H. C., "Flora of Turkey and the East Aegean Islands," Vol. 11, Edinburgh University Press, Edinburgh, 2000, pp. 136-138.

3) Baytop T., "Türkiye'de Bitkilerle Tedavi-Geçmisten Bugüne (Therapy with Medicinal Plants in Turkey-Past and Present)," 2nd ed., Nobel Tip Basimevi, Istanbul, 1999, p. 169.

4) Hohmann J., Pall Z., Guenther G., Mathe I., Planta Med., 63, 96 (1997).

5) Kartnig T., Wolf J., Planta Med., 59, 285 (1993).

6) Erdelmeier C. A. J., Sticher O., Phytochemistry, 25, 741 -743 (1986).

7) Erdelmeier C. A. J., Sticher O., Planta Med., 1985, 407-409 (1985).

8) Hiller K., Linzer B., Pharmazie, 21, 245-250 (1966).

9) D'Acquaria I., Di Giovanni M. C., Gasparini F., Misiti D., D’Arrigo C., Fagnano N., Guarnieri D., Iacono G., Bifulco G., Riccio R., Tetrahedron, 58, 10127-10136 (2002).

10) León I., Enríquez R. G., Gnecco D., Villarreal M. L., Cortés D. A., Reynolds W. F., Yu M., J. Nat. Prod., 67, 1552-1556 (2004).

11) Herlt A. J., Mander L. N., Pongoh E., Rumampuk R. J., J. Nat. Prod., 65, 115-120 (2002).

12) Voutquenne L., Lavaud C., Massiot G., Delaude C., Phytochemistry, 49, 2081-2085 (1998)

13) Della Greca M., Fiorentino A., Monaco P., Previtera L., Phytochemistry, 36, 1479-1483 (1994).

14) Burczyk J., Reznicek G., Baumgarten S., Hugh-Bloch M., Jurenitsch J., Schröder H., Werz U., Haslinger E., Phytochemistry, 39, 195-198 (1995).

15) Lavaud C., Massiot G., Le Men-Olivier L., Viari A., Vigny P., Delaude C., Phytochemistry, 31, 3177-3181 (1992).

16) Kuehner K., Voigt G., Hiller K., Rabe A., Franke P., Pharmazie, 39, $719-720$ (1984). 